\title{
The Effect of Spiritual Intelligence Santri Tirakatan Islamic Boarding School Jagad 'Alimussirry to Personal Financial Management
}

\author{
N D Damayanti ${ }^{1}$, M Priantini $^{2}$ \\ Accounting, Faculty of Economy, Surabaya State University \\ Email: novitadwidamayanti12@gmail.com
}

\begin{abstract}
Frequent discrepancies between income and expenditure by santri caused by a great desire to continue carrying out excessive consumption activities. Effectiveness and efficiency in financial management are closely related to the spiritual intelligence of each santri. SQ intelligence in managing personal finances will have an impact in driving good and right management goals. Allah in his word also gave an appeal to all his people to be able to manage well so that the realization of the benefit of life in the world and in the hereafter can be realized. The type of this research is the quantitative research methods. The research site was centered at the Islamic Boarding School Jagad 'Alimussirry Wonokromo Surabaya. In this study shows that spiritual intelligence has no influence on the process of managing personal finance.
\end{abstract}

Keywords: spiritual intelligence; managing personal finance

\section{INTRODUCTION}

Finance is important for every individual santri. However, money can bring significant problems when there is an error in managing it. This can lead to an imbalance between income and expenditure. For example in the phenomenon that occurred in Jagad 'Alimussirry Student Boarding School regarding the frequent discrepancies between the income and expenditure of the santri caused by a great desire to continue to carry out excessive consumption activities without thinking about financial conditions that were not profitable. So, in an effort to achieve financial well-being, there is a need for good financial management for every santri [1].

According to Yulius Eka in Faridawati \& Silvy [1], financial management is the management of financial functions related to how to obtain funds (raising of funds) and how to use the funds that have been obtained (allocation of funds). The adequacy and lack of finance for santri circles depends on the effectiveness and efficiency of financial management, which is closely related to the spiritual intelligence of each santri.

Humans are created by Allah SWT by having various kinds of intelligence. These intelligences include intelligence (intelligence quotient/IQ), emotional intelligence (emotional quotient/EQ), moral intelligence (moral quotient/MQ), spiritual intelligence (spiritual quotient/SQ) and intelligence in overcoming difficulties (adversity quotient/AQ).

IQ intelligence is the brain's ability to think to solve problems. EQ intelligence is based on human ability to manage emotions or feelings. MQ intelligence is more related to how to know the true or false values and demands to do the right thing. SQ intelligence relates to belief in God, in other words belief in God includes belief in all creation and power to humans so that the intelligence of SQ is not intended for the atheist group (not believing in God). Furthermore, AQ 
intelligence is defined as a facto $r$ to determine how, so his or walkin and extent of attitudes, capabilities and performance will be realized. High AQ intelligence will be better able to realize its ideals compared to low AQ intelligence [2].

SQ intelligence can give meaning to life that will encourage noble deeds in life. SQ intelligence can be associated with art in managing personal finances that have an impact on the goals of good and correct management and avoiding ways of financial accumulation that are biased. SQ intelligence can also lead to positive attitudes, including responsibility, independence, honesty and more optimal financial freedom which results in the opening of opportunities [3].

Spiritual intelligence can be obtained by humans by conducting ma'rifatullah studies by carrying out amaliah tirakat activities or riyadhah. So, it can be said that students who follow the tirakatan program will have good spiritual intelligence. Spiritual intelligence will trigger a race and sincere gratitude that results in clarity of mind of a man that will lead to new ways of thinking wise in attitude when managing personal finances. Allah in his word also gave an appeal to all his people to be able to manage well so that the realization of the benefit of life in the world and in the hereafter can be realized.

Several studies related to this research include research conducted by Garlans \& Noya [3] entitled The Effect of Spiritual Intelligence on Personal Financial Management with the results of research showing that there is a positive but not significant influence between spiritual intelligence and personal financial management due to the need for other factors to improve art in managing personal finances. Furthermore, research conducted by Faridawati \& Silvy [2] with the title Influence Intent to Conduct and Spiritual Intelligence to Manage Personal Finances with the results of studies showing that the intention to behave significant positive effect on the financial management of the family, while the spiritual intelligence positive effect but not significant family financial management

\section{METHOD}

This type of research is the author of quantitative research methods. The research site was centered at the Alimussirry Wonokromo Surabaya Student Boarding School. The population of this study is the santriwan/santriwati of Islamic Boarding School Students' Alimussirry who either carry out the process of tirakat or riyadhah or not. Meanwhile, the study sample was chosen randomly or randomly through a percentage of $50 \%$ of the students who took part in the tithe activities

\section{RESULT AND DISCUSSION}

The results of this study cannot support the results of D. Wulandari [4] which states that spiritual intelligence can also influence the organizational commitment of the PPJA Santri Executive Board. According to D. Wulandari [4], the daily place for students and female students who take part in BES is under the auspices of pesantren so that in their daily lives they are always accompanied by spiritual activities that will train the heart and the self to continue to involve God in all matters including in establishing commitment in an organization. However, according to research conducted Based on the research results of Peter Garlans Sina and Andris Noya [3], the acceptance of the null hypothesis means that spiritual intelligence does not absolutely improve the ability to manage personal money properly. Or in other words, spiritual intelligence which is intelligence giving value or interpreting life and contains various values of wisdom statistically is not always a predictor of the success of personal financial management. Meanwhile, the results of research by Ririt Faridawati and Mellyza Silvy [1] state that spiritual intelligence has a positive but not significant effect on personal financial management. The results of this study indicate that managing finances indeed requires spiritual intelligence, but to achieve success in managing finances that is right on target is not enough. 
Table. I T Test

\begin{tabular}{|c|c|c|c|c|c|c|}
\hline \multirow{2}{*}{\multicolumn{2}{|c|}{ Model }} & \multicolumn{2}{|c|}{$\begin{array}{c}\text { Unstandardized } \\
\text { Coefficients }\end{array}$} & \multirow{2}{*}{$\begin{array}{c}\text { Standardized } \\
\text { Coefficients } \\
\text { Beta } \\
\end{array}$} & \multirow[b]{2}{*}{$\mathrm{t}$} & \multirow[b]{2}{*}{ Sig. } \\
\hline & & B & Std. Error & & & \\
\hline \multirow[t]{2}{*}{1} & (Constant) & 43,434 & 14,379 & & 3,021 &, 006 \\
\hline & SQ & ,217 & , 177 &, 253 & 1,226 &, 233 \\
\hline
\end{tabular}

Based on the results of the tests conducted, it indicates that there is acceptance of the null hypothesis which means the spiritual intelligence of santri students in the Islamic Student Boarding School 'Alimussirry has not been able to improve personal management skills in each santri. More specifically, although the Islamic Boarding School Student Islamic Boarding School students 'Alimussirry already has an awareness of the importance of conducting a personal financial management process, it is not enough to improve the ability of personal financial management that is right on target.

\section{CONCLUSION}

Based on the results and discussion that has been carried out regarding the influence of the spiritual intelligence of the Islamic students of the Islamic Boarding School Students in Alimussirry on the personal financial management process it was found that the value of $t<t$ table $(1,226<2,07961)$ then $\mathrm{H} 0$ is accepted which means there is no influence between spiritual intelligence of the students of the Islamic Boarding School Student Association Alimussirry towards the process of managing personal finance. This is due to the need for other intelligences that can support success in the process of managing personal finance in accordance with Islamic Shari'a which is recommended by Allah SWT and the
Prophet Muhammad, including the ability to divide financial management into consumption, shodaqoh and others used for save process of managing personal finance. This is due to the need for other intelligences that can support success in the process of managing personal finance in accordance with Islamic Shari'a which is recommended by Allah SWT and the Prophet Muhammad, including the ability to divide financial management into consumption, shodaqoh and others used for save.

\section{REFERENCES}

[1] Faridawati, Ririt and Slivy, Mellyza, "Effect of Intention to Behavior and Spiritual Intelligence on Management of Family Finance." 2016, unpublished.

[2] S. Hilfan, "5 Types of Human Intelligence." 2014, [Accesed on November 23th, 2018: http://hilfan.staff.telkomuniversity.ac.id/id/2014/01/5 -types-intelligence-human/].

[3] P. G. Sina \& A. Noya, Effect of Spiritual Intelligence on Personal Finance management." Journal of Management, Vol. 1, No. 2, May 2012.

[4] D. Wulandari \& M. Priantini, The Influence of Spiritual Intelligence on the Organizational Commitments of Board Executive Santri (BES) Of PPJA." Journal Intellectual Soufism Research, Vol. 1, No. 2, May 2019.

[5] T.A Rohman, "Effect of Spiritual Intelligence on Organizational Commitment on IPPNU Tulungagung IPNU PC Management.” 2016, unpublished.

[6] NU Encyclopedia, "Tirakat." 2012 [Accesed on December 3rd, 2018: http://www.nu.or.id/post/read/40738/tirakat].

[7] A.Khori, "Management of Islamic Boarding Schools as the Treasures of Success of Islamic Education." Manageria: Journal of Islamic Education Management Volume 2, Number 1, May 2017/1438.

[8] Maghfirah, "Effect of Personal Financial Knowledge on Financial Management of Personal in Makassar City with Love of Money as an Intervening Variable." 2017, unpublished.

[9] F. N. Sari, "Effects of the Level of Religiosity of Santri Darussalam Kediri Islamic Boarding School Against Interest in Saving in Islamic Banking.” 2018, unpublished.

[10] D. Zohar and I. Marshall, SQ: Spiritual IntellegenceThe Ultimate Intelligence. Bloomsbury: Great Britain, 2000 . 